\title{
ZMIANA SYMULOWANA. TOTALITARYZM I TO, CO NASTĄPIŁO PÓŹNIEJ
}

\author{
Cristina Petrescu ${ }^{1}$ \\ (Universitatea din București)
}

\begin{abstract}
Słowa kluczowe: totalitaryzm, posttotalitaryzm, sprawiedliwość okresu przejściowego, sprawiedliwość tranzycyjna, demokratyzacja, edukacja, The Legacies of Totalitarianism, Aviezer Tucker
\end{abstract}

Keywords: totalitarianism, post-totalitarianism, transitional justice, democratization, education, The Legacies of Totalitarianism, Aviezer Tucker

\begin{abstract}
Abstrakt: Cristina Petrescu, ZMIANA SYMULOWANA. TOTALITARYZM I TO, CO NASTĄPIŁO PÓŹNIEJ. „PORÓWNANIA” 1 (24), 2019. T. XXIV, S. 263-267. ISSN 1733-165X. Mój komentarz dotyczy oceny wpływu totalitarnego, komunistycznego dziedzictwa na system edukacji. Zostało to przeprowadzone w jednym z rozdziałów książki Aviezera Tuckera, The Legacies of Totalitarianism. Według niego głównym dylematem posttotalitarnego uniwersytetu jest odpowiedź na pytanie, czy celem fundamentalnej restrukturyzacji szkolnictwa wyższego jest osiągnięcie autonomii, czy zagwarantowanie sobie poparcia państwa poprzez symulację zmiany. Tucker twierdzi, że system boloński oznacza transformację uniwersytetów w zarządzane przez państwo korporacje, które obniżają standardy nauczania i wprowadzają różne mechanizmy mierzenia aktywności naukowej. Autor przekonująco argumentuje, że nieintecjonalnym efektem przystąpienia byłych krajów komunistycznych do Unii Europejskiej jest powrót do znanego w okresie komunizmu modelu symulowania zmian w szkolnictwie wyższym.
\end{abstract}

Abstract: Cristina Petrescu, SIMULATED CHANGE: TOTALITARIANISM AND WHAT COMES NEXT. "PORÓWNANIA" 1 (24), 2019. Vol. XXIV, P. 263-267. ISSN 1733-165X. My intervention focuses on Aviezer Tucker's assessment of legacies of totalitarianism in the educational system. Tucker singles out a major dilemma of post-totalitarian universities: to fundamentally restructure in order to become autonomous or to simulate change while preserving state support. He contends that the Bologna system meant the transformation of universities into state-managed corporations that lowered standards and introduced various mechanisms of measuring performance. Thus, Tucker convincingly argues, the unwanted result of including the former communist coun-

1 E-mail: cristina.petrescu@fspub.unibuc.ro 
tries in the European Union was the return to a familiar model of simulated change in the field of education.

Pierwsze pytanie, jakie przychodzi na myśl podczas lektury książki Aviezera Tuckera, to pytanie o preferowaną przez niego koncepcję totalitaryzmu. Przez ostatnie 60 lat intensywnie spierano się o właściwe stosowanie i nadużywanie tej koncepcji. Jej krytycy na polu historii byli o wiele liczniejsi niż zwolennicy - nie bez przyczyny. Na podstawie rozmaitych źródeł i przy użyciu różnych metod stosowanych w badaniach nad systemami komunistycznymi zobrazowano $\mathrm{z}$ jednej strony porażkę władzy pragnącej wprowadzić całkowitą kontrolę życia społecznego przy zastosowaniu środków znajdujących się aktualnie w jej dyspozycji, a z drugiej strony zdolność kontrolowanych w wynajdywaniu rozmaitych strategii umożliwiających obronę przed wprowadzeniem takiego nadzoru. Historykom czarno-biały podział społeczeństwa komunistycznego na sprawców utrzymujących się u władzy (,ich”) i bezbronne ofiary („nas”) jawił się więc jako nieodpowiedni do wyjaśnienia tego, w jaki sposób systemy komunistyczne przetrwały 45 lat. Politolodzy bronili jednak takiej koncepcji totalitaryzmu. W klasycznej publikacji z 1975 roku, przedrukowanej w 2000 roku, Juan J. Linz zredefiniował tę koncepcję i bronił jej użyteczności, proponując prostą, lecz przekonującą, trzyelementową typologię, w ramach której odróżniał system demokratyczny od dwóch odmian systemu niedemokratycznego: autorytarnego i totalitarnego (Linz). W późnych latach osiemdziesiątych Giovanni Sartori zrewidował swoją teorię demokracji i wysunął argument, że stosowana dotychczas koncepcja totalitaryzmu może nie najlepiej służyć rozważaniom nad złożonością i różnorodnością społeczeństw komunistycznych w okresie postalinowskim, jednak brak jest trafniejszej koncepcji, która pozwalałaby lepiej wyjaśnić nieustanne dążenie tych systemów społecznych do sprawowania całkowitej kontroli (Sartori).

Tucker wpisuje się w tę tradycję myślenia politycznego, gdy opowiada się za zastosowaniem terminu totalitaryzm do systemów Europy Środkowo-Wschodniej przed 1989 rokiem i podejmuje problem ich stopniowego rozwoju w ciągu 45 lat ich dominacji. Odróżnia on totalitaryzm rewolucyjny, ukierunkowany na fundamentalne przekształcenie społeczeństwa, od późnego totalitaryzmu, którego celem miało być zachowanie skonsolidowanego ustroju politycznego i systemu społecznego: „Późny reżim totalitarny zaprzestał prób zmieniania natury ludzkiej. Zamiast tego wzmacniano pobudki egoistyczne i manipulowano zachowaniami oportunistycznymi" (Tucker 2015: 9) ${ }^{2}$. W tym okresie nie tylko nastąpił zanik ambicji zmieniania społeczeństwa, ale też osłabł terror. Późny totalitaryzm według Tuckera pokrywa się mniej więcej ze zjawiskiem, które dysydenci zwykli w swoich krytycznych tekstach określali mianem posttotalitaryzmu. Wydaje się jednak, że autor nie zważa na wnikliwe, dokonywane często z pierwszej ręki, obserwacje byłych dysydentów

2 Tłumaczenia cytatów pochodzą od tłumaczki artykułu - A.W. 
na temat współczesnych im społeczeństw, które tak często analizował w swoich wcześniejszych pracach. Co więcej, Tucker zdaje się zgadzać z postkomunistycznymi oportunistami, którzy stosowali termin totalitaryzm do opisu 45 lat komunizmu w Europie Środkowo-Wschodniej. Zwalniało ich to z wszelkiej odpowiedzialności za uleganie władzom, pomimo że opór nie był już surowo karany. Tucker gra jednak o zupełnie inną stawkę - zwraca uwagę nie na to, co zdarzyło się przed 1989 rokiem, lecz na to, co wydarzyło się później. W omawianej publikacji przekonywująco wyjaśnia ewolucję Europy Środkowej i Wschodniej po 1989 roku, przesuwając punkt ciężkości ze społeczeństwa obywatelskiego, którego znaczenie przed 1989 rokiem było, jak słusznie zauważa, raczej znikome w państwach tego regionu (Polska stanowiła w pewnej mierze wyjątek od tej zasady) i które powstało raczej na skutek zmiany systemu, niż samo do tej zmiany się przyczyniło. Autor analizuje zdolność elit późnego totalitaryzmu do zachowania kontroli w okresie posttotalitarnym, wyjaśniając transformację ustrojową jako „spontaniczny rezultat dostosowania praw późnototalitarnej elity do jej interesów i przekształcenie jej niepisanych swobód w prawa, przede wszystkim prawa własności" (Tucker 2015: 22).

Zastosowanie przez Tuckera terminu posttotalitaryzm jako synonimicznego z systemami społecznymi wyłonionymi po 1989 roku, a nie z systemami poststalinowskimi, motywowane jest również pragnieniem porównania reżimów posttotalitarnych z postautorytarnymi. We wcześniejszych swoich pracach nad sprawiedliwością okresu przejściowego w Europie Środkowo-Wschodniej Tucker nakreślił pewne różnice pomiędzy nimi. Społeczeństwa postautorytarne skorzystały na istnieniu mającego stosunkowo duże znaczenie społeczeństwa obywatelskiego i autentycznych profesjonalistów w wielu kluczowych dziedzinach życia społecznego. Transformacja ustrojowa była więc rezultatem negocjacji pomiędzy starymi a nowymi elitami. W systemach posttotalitarnych natomiast społeczeństwo obywatelskie, jeśli w ogóle istniało, było słabe i w nim brakowało specjalistów o demokratycznych poglądach, którzy mogliby wspierać transformację. Krótko mówiąc, w społeczeństwach posttotalitarnych „brak jest alternatywnych elit w obszarach wymiaru sprawiedliwości, bezpieczeństwa i administracji” (Tucker 2006: 182). W następnej dekadzie krajobraz polityczny w Europie Środkowo-Wschodniej zmienił się na gorsze. Paradygmat demokratyzacji, który starał się wyjaśniać problemy w procesie demokratyzacji, został porzucony, a pojawienie się tak zwanych demokracji nieliberalnych zmodyfikowało stawiane pytania badawcze. Tucker rozwija więc swoje porównanie tak, aby wyjaśnić, co wyróżnia dziedzictwa posttotalitarne i sprawia, że o wiele trudniej jest pozbyć się ich niż dziedzictw postautorytarnych. Gdy elity posttotalitarne skupiają się na przekształceniu władzy politycznej w bogactwo ekonomiczne i prywatyzują własność państwową z korzyścią dla siebie, to nadzór rządu nad biurokracją wykonawczą jest nieefektywny, społeczeństwo obywatelskie - słabe, poziom korupcji - wysoki, rządy prawa w rzeczywistości nie występują, a ideologie polityczne nie są narzędziem mobilizowania elektoratu. Co więcej, 
byli funkcjonariusze policji politycznej nadal kontrolują politykę, gospodarkę i media, sprawcy pozostają w dużej mierze bezkarni, ich ofiary zaś nie mogą doczekać się zadośćuczynienia za doznane krzywdy.

Jak zostało już wcześniej zaobserwowane przez wielu komentatorów, dziedzictwa totalitaryzmu są w książce badane w kilku rozdziałach poświęconych dostosowywaniu praw byłych elit totalitarnych do ich interesów i temu, jak niewydolny jest system sprawiedliwości okresu przejściowego w wymierzaniu kar i egzekwowaniu rekompensat. Moją uwagę przyciąga w szczególności kwestia pozostałości po totalitaryzmie w systemie edukacji. Niewątpliwie stanowią one kluczowy aspekt socjalizacji kolejnych pokoleń i laboratorium odtwarzania starych wzorców myślenia. Niektórzy recenzenci uznali ten rozdział za mniej uzasadniony teoretycznie. Mnie jednak, jako osobie, która wyszła z posttotalitarnego systemu edukacji, wydaje się, że empiryczne dowody doprowadziły Tuckera do trafnych wniosków. Posttotalitarne uniwersytety stanęły najwyraźniej w obliczu dylematu dotyczącego projektu instytucji: czy należy dokonać gruntownej restrukturyzacji celem uzyskania autonomii, czy też symulować zmianę, zachowując jednocześnie wsparcie państwa. W różnym stopniu w poszczególnych państwach dokonano dość istotnych reform systemu edukacyjnego, obejmujących między innymi wprowadzenie publicznego, transparentnego zarządzania, profesjonalizacji kadry akademickiej i modernizacji programów nauczania. Jednakże, paradoksalnie, ich efekt może stanowić ilustrację argumentu Alberta Otto Hirschmana o daremności (Hirschman). W przeciwieństwie do poprzednich rozdziałów, w których dziedzictwa totalitarnej przeszłości omawiane są jako czynniki wpływające na rzeczywistość posttotalitarną, w rozdziale o edukacji aktualny stan uniwersytetów w postkomunistycznej Europie przedstawiany jest raczej jako bezpośredni skutek westernizacji, która nastąpiła po 1989 roku. W systemie bolońskim, w którym skodyfikowano istniejący już trend ekspansji szkolnictwa wyższego w Europie Zachodniej, dokonano przemiany uniwersytetów w korporacje zarządzane przez państwa. Konieczne stało się obniżenie standardów i wprowadzenie różnych sposobów mierzenia wyników pracy akademickiej. W związku z tym Tucker przekonująco argumentuje, że niechcianym skutkiem włączenia byłych krajów komunistycznych do Unii Europejskiej był powrót do znajomego modelu edukacji:

Nowy, zarządzany publicznie uniwersytet to parodia uniwersytetu, wioska potiomkinowska, pozór uczelni. Zamiast nauczania jest oszukiwanie, zamiast dialogów sokratejskich - wypunktowania, [...] zamiast życia w prawdzie, intelektem i duchem, życie akademickie toczy się pod znakiem wdrażania absurdów, bezsensu, niemoralności i szkodliwych zasad sączonych z góry przez anonimową i zwolnioną z odpowiedzialności biurokratyczną hierarchię (Tucker 2015: 203).

Jakie to prawdziwe! 
Książkę warto przeczytać nie tylko z uwagi na te trafne spostrzeżenia. Jej treść jest bardzo aktualna, a autor argumentuje w klarowny i atrakcyjny sposób. Znajdziemy tu też wiele fraz zapadających w pamięć, takich jak: „totalitaryzm nie umarł, lecz tylko uległ dezintegracji" (Tucker 2015: 233). Publikacja ta z pewnością wejdzie do kanonu literatury na temat postkomunizmu, posttotalitaryzmu i - miejmy nadzieję, mimo trudnej sytuacji - demokratyzacji w Europie Środkowo-Wschodniej.

Przet. Agnieszka Wróblewicz

\section{BIBLIOGRAFIA}

Hirschman, Albert O. Exit, Voice, and Loyalty: Responses to Decline in Firms, Organizations, and States. Cambridge, MA: Harvard University Press, 1970.

Linz, Juan J. Totalitarian and Authoritarian Regimes. Londyn: Lynne Rienner Publishers, 2000.

Sartori, Giovanni. The Theory of Democracy Revisited. Chatham, NJ: Chatham House, 1987.

Tucker, Aviezer. The Legacies of Totalitarianism: A Theoretical Framework. Nowy Jork: Cambridge University Press, 2015.

Tucker, Aviezer. „Paranoids May Be Persecuted: Post-totalitarian Transitional Justice”. Retribution and Reparation in the Transition to Democracy. Red. J. Elster. Cambridge: Cambridge University Press, 2006. S. 181-205. 
